\title{
Examination of Titratable Acidity, pH, Total Lactic Acid Bacteria and Sensory Properties in Whey Fermented with Probiotic Pediococcus acidilactic BK01
}

\section{Sri Melia ${ }^{1 *}$, Indri Juliyarsi ${ }^{1}$, Yulianti Fitri Kurnia ${ }^{1}$, Yudha Endra Pratama ${ }^{2}$, Huriya Azahra ${ }^{3}$}

${ }^{1}$ Faculty of Animal Science Universitas Andalas., Padang, West Sumatra, Indonesia. 25163; ${ }^{2}$ Postgraduate Program at Faculty of Animal Science, Universitas Andalas, Padang, West Sumatra, Indonesia; ${ }^{3}$ Magister program of Animal Science, Universitas Andalas, Padang, West Sumatra, Indonesia.

\begin{abstract}
This study aimed to determine the influence of the fermentation period on titratable acidity, $\mathrm{pH}$, total lactic acid bacteria, and sensory properties in fermented whey with the addition of Pediococcus acidilactici BK01 as a probiotic. Whey was obtained as a by-product of processing cheese from Etawa crossbreed goat milk. The whey fermentation period was $10,12,14,16,18$, and 20 hours. Based on the results, the fermentation period significantly $(\mathrm{P}<0.05)$ decreased $\mathrm{pH}$ and increased total lactic acid bacteria and titratable acidity. The $\mathrm{pH}$ of fermented whey was $5.10 \pm 0.00$ to $5.20 \pm 0.00$, and total lactic acid bacteria of fermented whey was $38.7 \pm 0.84$ to $88.7 \pm 0.19 \times 10^{10} \mathrm{CFU} / \mathrm{mL}$. Titratable acidity of fermented whey was $0.51 \pm 0.01$ to $0.61 \pm 0.05$. Based on the organoleptic test, panelists liked the fermented goat milk whey.
\end{abstract}

Keywords | Goat milk, Whey, By product, Cheese, Fermentation times

Received | September 09, 2021; Accepted | October 28, 2021; Published | December 01, 2021

*Correspondence | Sri Melia, Faculty of Animal Science Universitas Andalas., Padang, West Sumatra, Indonesia. 25163; Email: srimelia75@ansci.unand.ac.id Citation | Melia S, Juliyarsi I, Kurnia YF, Pratama YE, Azahra H (2022). Examination of titratable acidity, pH, total lactic acid bacteria and sensory properties in whey fermented with probiotic Pediococcus acidilactic BK01. Adv. Anim. Vet. Sci. 10(1): 114-119.

DOI | http://dx.doi.org/10.17582/journal.aavs/2022/10.1.114.119

ISSN (Online) | 2307-8316; ISSN (Print) | 2309-3331

Copyright (C) 2022 Melia et al. This is an open access article distributed under the Creative Commons Attribution License, which permits unrestricted use, distribution, and reproduction in any medium, provided the original work is properly cited.

\section{INTRODUCTION}

W They is a severe problem for dairy factories because waste containing organic compounds threatens the ecosystem (Wesołowska-Trojanowska and Targoński, 2014). Whey comes from cow, sheep, goat, or camel milk (Salvatore et al., 2014; Philippopoulos and Papadakis, 2001; Laleye et al., 2008). Whey is produced in nine parts in the cheese-making process, while cheese is only one (Bylund, 2003). Whey is a yellow liquid with a slightly sour taste separated from the curd in the cheese-making process. Whey is grouped into two types based on the milk coagulation method: sweet whey and sour whey (Skryplonek and Jasińska, 2017; Smithers, 2008; De Wit, 2001). Sweet whey is enzymatic coagulation of milk by chymosin with a $\mathrm{pH}$ of 6-7 and is also known as cheese whey, while sour whey is a by-product of milk coagulation through acidification with a $\mathrm{pH}<5$ (Lievore et al., 2015).
Whey protein is a derivative as a food aspect with essential vitamins and has purposeful residences to be popular as an intended food aspect. Commercial whey protein is considered a GRAS (Generally Recognized As Safe) substance or secure for food product applications (Sinha et al., 2007). Various types of whey ingredients are available for producing yogurt and fermented beverages, namely sweet whey powder (SWP), whey protein concentrate (WPC), whey protein isolate (WPI), and special WPC (Hugunin, 2008). Whey protein has a high biological value and is superior to other proteins such as egg, soybean, and milk casein, especially in its high content of essential amino acids (Pescuma et al., 2010; Shiby et al., 2013). In addition, whey can be further processed into a fermented beverage with probiotic bacteria beneficial for digestive health to increase the economic value.

Probiotic bacteria have good effects on the body, such 
as increasing the immune system, preventing intestinal, diarrhea, and gastritis by destroying pathogenic bacteria (Walsh et al., 2010; Melia et al., 2017). Based on several studies, the probiotic lactic acid bacteria are also obtained from buffalo, goat, and cow milk (Melia et al., 2019) by being developed in fermented goat milk products for several storage times (Melia et al., 2019, 2020). Consumer interest in functional foods or drinks containing probiotics and prebiotic increases and creates a huge market to develop (Rathore et al., 2012; Walsh et al., 2010). Consumer demand for food and beverages with nutritional benefits is rapidly growing, resulting in various value-added dairy products (Shiby et al., 2013). The probiotic bacteria used in this study was Pediococcus acidilactici BK01 with probiotic and has antimicrobial activity (Melia et al., 2019).

Whey-based beverages with lactic acid bacteria require sensory and physicochemical properties in product development and quality control (Almeida et al., 2009). Furthermore, consumer acceptance of health drinks depends on developing nutritional drinks by maintaining the characteristics of taste, appearance, and texture during storage and consumption (Shiby et al., 2013). This research aimed to evaluate the influence of the fermentation times on titratable acidity, $\mathrm{pH}$, total lactic acid bacteria, and sensory properties in fermented whey with the addition of Pediococcus acidilactici BK01 as a probiotic.

\section{MATERIALS AND METHODS}

This study used Etawa crossbreed goat milk and Pediococcus acidilactici BK01 as novel probiotics (Melia et al., 2020). This study was conducted at the Laboratory of Animal Product Processing Technology, Universitas Andalas.

\section{STARTER PREPARATION}

Preparation of fermented whey starter referred to (Tamime, 2006) with modifications to the incubation time. Whey was pasteurized at $83-85^{\circ} \mathrm{C}$ for 30 minutes and allowed to stand until $\pm 40{ }^{\circ} \mathrm{C}$. Pediococcus acidilactici $\mathrm{BK} 01$ was put into whey and incubated at $37^{\circ} \mathrm{C}$ for 18 hours.

\section{FERMENTED WHEY PRODUCTION}

Based on (Tamime, 2006) the production manufacture of pasteurized fermented whey was added with $0.3 \%$ carboxyl methylcellulose (CMC) as a stabilizer. The pasteurized whey temperature was lowered to $40^{\circ} \mathrm{C}$. Starter as much as $4 \%$ was added and fermented for 10,12, 14, 16, 18, 20 hours and incubated at $37^{\circ} \mathrm{C}$.

\section{Titratable ACIDITY TEST}

A total of $10 \mathrm{~mL}$ of the sample was taken with a volumetric pipette, then put into a beaker after it was given phenolphthalein indicator, then titrated with $0.1 \mathrm{M} \mathrm{NaOH}$ solution until a consistent pink color (Parmar, 2003).

\section{$\mathrm{PH}$}

The degree of acidity of the whey fermentation was measured using by $\mathrm{pH}$ meter and calibrated with a buffer solution with a $\mathrm{pH}$ value of 3 and 7 . Prepare a sample of 5 $\mathrm{mL}$, then add $10 \mathrm{~mL}$ of distilled water. After that, stir the piece for 5 minutes (AOAC, 2005).

\section{COUNT OF LACTIC ACID BACTERIA}

Prepare a sample of $1 \mathrm{~mL}$, then dissolve it in a test tube containing $9 \mathrm{~mL}$ of de Man Rogosa Sharpe Broth $\left(\right.$ Merck $^{\mathrm{TM}}$, Germany) solution, then vortex until homogeneous. Then serial dilution was carried out. The samples were planted using the spread method on a Petri dish containing MRS Agar and then flattened using a hockey stick previously given alcohol and burned. Next, prepare the inoculum with an anaerobic jar, put it in an incubator at $37^{\circ} \mathrm{C}$ for 48 hours, and then code the Petri dish by marking each petri dish. After 48 hours, the growing colony was viewed with the Quebec Colony Counter (Harley and Prescott, 2002).

\section{SEnSORY AnALYSIS}

The sensory test used the hedonic scoring scale method (1-5), namely ( $1=$ dislike extremely; $2=$ dislike slightly; $3=$ neither like nor dislike; $4=$ like slightly; $5=$ like extremely). Their taste, aroma, and texture distinguished fermented whey beverage. Panelists consist of students and employees in the Department of Animal Products Technology Laboratory.

\section{STATISTICAL ANALYSis}

The data were analyzed using SPSS statistics 23, and if there was a significant difference from the treatment, it was continued with Duncan Multiple Range Test (DMRT).

\section{RESULTS AND DISCUSSION}

\section{TitratABLE ACIDITY}

Titratable acidity on fermented whey Pediococcus acidilactici BK01 with different fermentation times significantly decreased $(\mathrm{P}<0.05)$. Table 1 shows the results of titratable acidity in fermented whey.

Table 1 shows the value of titratable acidity in fermented whey with a difference in fermentation time of $0.51 \pm 0.01$ to $0.61 \pm 0.05$. There was a very significant increase in acidity at 20 hours of fermentation. Duration of fermentation determined lactic acid production. The longer the fermentation time, the higher the lactic acid production produced by these bacteria. Kaur et al. (2019) state Pediocoocus is a probiotic that has been widely applied in the field of biotechnology and applications in fermented foods. This bacterium belongs to the GRAS group, 
which is homofermentative, Gram-positive, and catalasenegative. The increase in titratable acidity is caused by lactic acid produced by the hydrolysis of lactose during the fermentation by lactic acid bacteria as primer metabolic (Lourens-hattingh and Viljoen, 2001; Kailasapathy, 2006). Therefore, many cultures must obtain the desired acid production and causes a dropping $\mathrm{pH}$ (Rathore et al., 2012). The ideal lactic acid bacteria should be fast and stable in acid production (Cho et al., 2013). Campagne et al. (2010) added that the lactic acid bacteria culture could affect growth and acidification.

Table 1: Titratable Acidity fermented whey.

\begin{tabular}{ll} 
Fermentation time (Hours) & Titratable acidity \\
\hline 10 & $0.51^{\mathrm{a}} \pm 0.01$ \\
12 & $0.57^{\mathrm{a}} \pm 0.05$ \\
14 & $0.56^{\mathrm{a}} \pm 0.00$ \\
16 & $0.54^{\mathrm{a}} \pm 0.03$ \\
18 & $0.56^{\mathrm{a}} \pm 0.01$ \\
20 & $0.61^{\mathrm{b}} \pm 0.05$
\end{tabular}

abDifferent superscripts in the same column showed significant differences $(\mathrm{P}<0.05)$.

This result is similar to the research of Sharma et al. (2021), which states that the accumulation of lactic acid during fermentation can increase titratable acidity. The results of this study were lower than Shukla et al. (2013). The fermented whey of Lactobacillus acidopbilus NCDC-015 had a titratable acidity of $0.394-1.353 \%$. It is because the bacteria Lactobacillus acidophilus could produce organic acids in higher quantities. Furthermore HernandezMendoza et al. (2007), making fermented whey with $L$. reuteri and $B$. bifidum had titratable acidity of 0.315 to $0.378 \%$ for 30 days storage.

\section{$\mathrm{PH}$}

The $\mathrm{pH}$ value of fermented whey with the addition of Pediococcus acidilactici BK01 with different fermentation periods significantly decreased the $\mathrm{pH}(\mathrm{P}<0.05)$. Table 2 shows the average $\mathrm{pH}$ value of fermented whey.

Table 2: The $\mathrm{pH}$ of fermented whey.

\begin{tabular}{ll} 
Fermentation times (Hours) & $\mathbf{p H}$ \\
\hline 10 & $5.20^{\mathrm{b}} \pm 0.00$ \\
12 & $5.20^{\mathrm{b}} \pm 0.00$ \\
14 & $5.13^{\mathrm{ab}} \pm 0.05$ \\
16 & $5.16^{\mathrm{ab}} \pm 0.05$ \\
18 & $5.13^{\mathrm{ab}} \pm 0.05$ \\
20 & $5.10^{\mathrm{a}} \pm 0.00$ \\
\hline
\end{tabular}

${ }^{a b}$ Different superscripts in the same column showed significant differences $(\mathrm{P}<0.05)$.
Table 2 shows that the fermentation period had a significant effect $(\mathrm{P}<0.05)$ on the $\mathrm{pH}$ value with a value range of $5.10 \pm 0.00$ to $5.20 \pm 0.00$. The lowest $\mathrm{pH}$ value was found in whey with fermentation for 20 hours with a $\mathrm{pH}$ value of $5.10 \pm 0.00$. While the highest $\mathrm{pH}$ value was found in fermented whey with fermentation for 10 hours and 12 hours with a $\mathrm{pH}$ value of $5.20 \pm 0.00$.

One of the characteristics of fermentation by lactic acid bacteria is the production of various organic acids due to the decomposition of multiple components in the raw material and a decrease in the $\mathrm{pH}$ of the product (Wu et al., 2011). Therefore, organic acids in fermented dairy products became indicators of the metabolic activity of other bacterial cultures. In addition, this acid acts as a natural preservative and contributes to the product's sensory properties (Adhikari et al., 2002).

The results of this research were higher than those of Shukla et al. (2013). The $\mathrm{pH}$ of fermented whey with Lactobacillus acidophilus NCDC-015 was 4.82-3.30 with 5 to 24 hours of fermentation times. Previously (Hernandez-Mendoza et al., 2007), making fermented whey with the addition of $L$. reuteri and B. bifidum resulted in a $\mathrm{pH}$ of 4.85 to 4.50 for 30 days of storage.

\section{TOTAL LACTIC ACID BACTERIA}

Total lactic acid bacteria in fermented whey with the addition of Pediococcus acidilactici BK01 with different fermentation periods significantly increased $(\mathrm{P}<0.05)$ on total lactic acid bacteria. Table 3 shows the average results of total lactic acid bacteria in fermented whey.

Table 3: Total lactic acid bacteria of fermented whey.

\begin{tabular}{|ll}
$\begin{array}{l}\text { Fermentation times } \\
\text { (Hours) }\end{array}$ & $\begin{array}{l}\text { Total average of BAL } \\
\left(\mathbf{1 0}^{\mathbf{1 0}} \mathbf{C F U} / \mathbf{m L}\right)\end{array}$ \\
\hline 10 & $40.3^{\mathrm{a}} \pm 0,88$ \\
12 & $38.7^{\mathrm{a}} \pm 0.84$ \\
\hline 14 & $39.0^{\mathrm{a}} \pm 0.85$ \\
16 & $63.7^{\mathrm{ab}} \pm 0.22$ \\
\hline 18 & $88.7^{\mathrm{b}} \pm 0.19$ \\
\hline 20 & $71.7^{\mathrm{ab}} \pm 0.37$ \\
\hline
\end{tabular}

${ }^{a b}$ Different superscripts in the same column showed significant differences $(\mathrm{P}<0.05)$.

Table 3 shows that fermented whey with different fermentation periods significantly affected $(\mathrm{P}<0.05)$. Total lactic acid bacteria in fermented whey with differences in fermentation time ranging from $38.7 \pm 0.84$ to $88.7 \pm 0.19$ $\times 10^{10} \mathrm{CFU} / \mathrm{mL}$. The lowest total lactic acid bacteria was in fermentation for 12 hours of $38.7 \pm 0.84 \times 10^{10} \mathrm{CFU} /$ $\mathrm{mL}$, while the highest total bacteria was in fermentation for 18 hours at $88.7 \pm 0.19 \times 10^{10} \mathrm{CFU} / \mathrm{mL}$. Previous studies have revealed a relationship between a decrease in $\mathrm{pH}$ 
and increased titratable acidity during fermentation. $\mathrm{pH}$ reduction during fermentation by lactic acid bacteria due to a rise in the amount of lactic acid has affected the value of titratable-acidity (Sebastian et al., 2018).

The result of this research was higher than the study of Shukla et al. (2013). The total lactic acid bacteria in fermented whey with Lactobacillus acidophilus NCDC-015 ranged from $2.21 \times 10^{7}$ to $9.69 \times 10^{8} \mathrm{CFU} / \mathrm{ml}$. Previously (Hernandez-Mendoza et al., 2007), making fermented whey with $L$. reuteri and B. bifidum resulted in total lactic acid bacteria reaching $10^{8} \mathrm{CFU} / \mathrm{mL}$. Lactic acid content increased rapidly as 3.5 times during fermentation (Adhikari et al., 2002). To have positive effects on health, the number of probiotic bacteria in food or beverage products must be high enough, $10^{6}-10^{8} \mathrm{CFU} / \mathrm{mL}$ (Najgebauer-Lejko, 2014).

\section{SEnSory ANALYSIS}

Based on the sensory analysis test results in Figure 1, It can be seen that fermented whey with a fermentation period of up to 18 to 20 hours was preferred in the taste and aroma. While the fermentation period, panelists' assessment had no significant effect on texture $(\mathrm{P}>0.05)$. The longer the fermentation period, the higher the amount of acid produced by Pediococcus acidilactici BK01. Pedicoocus acidilactici has the potential as lactic acid bacteria that play a role in increasing flavor. In previous studies, $P$. acidilactici BD16 was used to produce vanillin, and recombinant Pediococcus acidilactici BD16 ( $\mathrm{fcs}(+) /$ ech (+)) played a role in increasing the flavor of wine (Kaur et al., 2013, 2015).

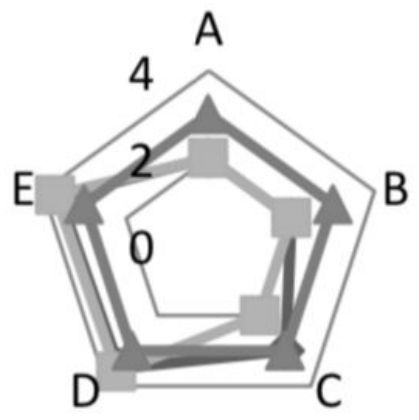

\section{$\sim$ Taste - Flavor - Texture}

Figure 1: Sensory analysis fermented whey Pediococcus acidilactici BK01.

Following the opinion of (Rathore et al., 2012), a high total lactic acid bacteria was needed to produce acid and cause a decrease in $\mathrm{pH}$ that affects the sensory properties of the final product and its shelf life and prevents contamination. (Davidson, 2000) stated that acidity is an essential attribute in product taste assessment. Adhikari et al. (2002) reveal organic acids are indicators of metabolic activity produced by bacteria added to fermented milk products. This acid is a natural preservative and plays a role in the characteristic sensory properties. In addition, the sweetness of sweet whey also affected the panelists' preference for fermented whey. It is supported by (Papademas and Kotsaki, 2019) opinion that sweet whey contains $46-52 \mathrm{~g} / 1$ lactose.

\section{CONCLUSIONS AND RECOMMENDATIONS}

Fermented whey made from goat milk with the addition of the probiotic Pediococcus acidilactici BK01 with different fermentation periods showed a significant effect $(\mathrm{P}<0.05)$ on titratable acidity of $0.61 \pm 0.05, \mathrm{pH}$ value of $5.10 \pm 0.00$, and total lactic acid bacteria of $88.7 \pm 0.19$ and a fermentation period of 18 to 20 were favored by the panelists.

\section{ACKNOWLEDGMENTS}

This research is supported by research cluster publications to professors T/8/UN.16.17/PP. Pangan-PDU-KRP2GBUnand/LPPM/ 2021.

\section{NOVELTY STATEMENT}

The novelty of this research is the utilization of the probiotic bacteria Pediococcus acidilactici BK01 in the processing of fermented whey. This bacteria was isolated from Bekasam, which is fermented fish, a typical food originating from South Sumatra, Indonesia.

\section{AUTHOR'S CONTRIBUTION}

All authors contributed to writing this manuscript.

\section{CONFLICT OF INTEREST}

The authors have declared no conflict of interest.

\section{REFERENCES}

-Adhikari K, Grûn IU, Mustapha A, Fernando LN (2002). Changes in the profile of organic acidity in plain set and stirred yogurts during manufacture and refrigerated storage. J. Food Qual., 25: 435-451. https://doi. org/10.1111/j.1745-4557.2002.tb01038.x

-Almeida KE, Tamime AY, Oliveira MN (2009). Influence of total solids contents of milk whey on the acidifying profile and viability of various lactic acid bacteria. LWT-Food Sci. Technol., 42: 672-678. https://doi.org/10.1016/j. lwt.2008.03.013

-AOAC (2005). Official methods of analysis. Association of Official Analytical Chemists. Benjamin Franklin Station. Washington.

-Bylund G (2003). Dairy processing handbook. Tetra Pak 
Processing Systems. Sweden.

- Campagne CP, Tompkins TA, Buckley ND, Green-Johnson JM (2010). Effect of fermentation by pure and mixed cultures of Streptococcus thermophilesand Lactoba-cillus helveticuson isoflavone and B-vitamin content of a fermented soy beverage. Food Microbiol., 27: 968-972. https://doi. org/10.1016/j.fm.2010.06.003

- Cho YH, Hong SM, Kim CH (2013). Isolation and characterization of lactic acidity bacteria from kimchi, Korean traditional fermented food to apply into fermented dairy products. Korea. J. Food Sci. A., 33: 75-82. https://doi. org/10.5851/kosfa.2013.33.1.75

-Davidson SE, Duncan CR, Hackney WN, Eigel JW (2000). Boling, Probiotic culture survival and implications in fermented frozen yogurt characteristics.J. Dairy Sci., 83: 666673. https://doi.org/10.3168/jds.S0022-0302(00)74927-7

-De Wit JN (2001). Lecturer's Handbook on whey and whey products. Eur. Whey Prod. Assoc. Brussels. Belgium.

- Harley JP, Prescott LM (2002). Laboratory exercises in microbiology. $5^{\text {th }}$ ed. New York: The McGraw-Hill Companies.

-Hernandez-Mendoza A, Robles VJ, Angulo JO, De La Cruz J, Garcia HS (2007). Preparation of a whey-based probiotic product with Lactobacillus reuteri and Bifidobacterium bifidum. Food Technol. Biotechnol., 45(1): 27-31.

-Hugunin A (2008). US whey ingredients in yogurt and yogurt beverages. US Dairy Export Council. Retrieved Jun 20, 2021, from http://usdec.files.cms-plus.com/ PDFs/2008Monographs/Yogurt Monograph2009.pdf

- Kailasapathy K (2006). Survival of free and encapsulated probiotic Bacteria and their effect on the sensory properties of yogurt. LWT- Food Sci. Technol., 39(10): 1221-1227. https://doi.org/10.1016/j.lwt.2005.07.013

-Kaur B, Chakraborty D (2013). Statistical media and process optimization for biotransformation of rice bran to vanillin using Pediococcus acidilactici. Indian J. Exp. Biol., 51: 935943.

- Kaur B, Kumar B, Kaur G, Chakraborty D, Kaur K (2015). Application of recombinant Pediococcus acidilactici BD16 $(\mathrm{fcs}(+) / \mathrm{ech}(+))$ in malolactic fermentation. Appl. Microbiol. Biotechnol., 99: 3015-3028. https://doi.org/10.1007/ s00253-015-6413-8

- Kaur T, Balgir PP, Kaur B (2019). Construction of a shuttle expression vector for lactic acid bacteria. J. Genet. Eng. Biotechnol., 17(10). https://doi.org/10.1186/s43141-0190013-4

-Laleye LC, Jobe B, Wasesa AAH (2008). Comparative study on heat stability and functionality of camel and bovine milk whey proteins. J. Dairy. Sci., 91: 4527-4534. https://doi. org/10.3168/jds.2008-1446

- Lievore P, Simoes DRS, Silva KM, Drunkler NL, Barana AC, Nogueira A (2015). Chemical characterization and application of acidity whey in fermented milk. J. Food Sci. Technol., 52(4): 2083-2092. https://doi.org/10.1007/ s13197-013-1244-z

-Lourens-hattingh A, Viljoen BC (2001). Yogurt as probiotic Carrier food. Int. Dairy J., 11(1): 1-17. https://doi. org/10.1016/S0958-6946(01)00036-X

- Melia S, Ferawati, Zulkarnain I, Yuherman, Jaswandi, Purwati E (2019). Quality, viability, and anti-bacterial properties of Lactobacillus fermentum NCC2970 in probiotic fermented goat milk at $4{ }^{\circ} \mathrm{C}$. Asian Jr. Microbiol. Biotech. Environ. Sci., 21(2): 237-242.
- Melia S, Juliyarsi I, Kurnia YF, Pratama YE, Pratama DR (2020). The quality of fermented goat milk produced by Pediococcus acidityilactici BK01 on refrigerator temperature. Biodiversitas, 21(10): 4591-4596. https://doi.org/10.13057/ biodiv/d211017

- Melia S, Kurnia YF, Purwati E, Pratama DR (2019). Antimicrobial potential of Pediococcusacidilactici BK01 from Bekasam, fermentation of sepatrawa fish (Tricopodustrichopterus) from Banyuasin, South Sumatra, Indonesia. Biodiversitas, 20(12): 3532-3538. https://doi. org/10.13057/biodiv/d201210

- Melia S, Yuherman, Jaswandi, Purwati E, Aritonang S, Silaen M (2017). Characterization of the antimicrobial activity of lactic acidbacteria isolated from buffalo milk in West Sumatra (Indonesia) against Listeria monocytogenes. Pak. J. Nutr., 16(8): 645-650. https://doi.org/10.3923/pjn.2017.645.650

- Najgebauer-Lejko D (2014). Effect of green tea supplementation on the microbiological, antioxidant, and sensory properties of probiotic milks. Dairy Sci. Technol., 94: 327339. https://doi.org/10.1007/s13594-014-0165-6

- Papademas P, Kotsaki P (2019). Technological utilization of whey towards sustainable exploitation. J. Adv. Dairy Res., 7: 231 .

- Parmar R (2003). Incorporation of acid whey powders in probiotic yogurt. M. Sc. thesis, Major in Biological Sciences, Specialization in Dairy, South Dakota State University, U.S.A.

-Pescuma M, Hébert EM, Mozzi F, Font de Valdez G (2010). Functional fermented whey-beverage using lactic acidity bacteria. Int. J. Food Microbiol., 141: 73-81. https://doi. org/10.1016/j.ijfoodmicro.2010.04.011

- Philippopoulos CD, Papadakis MT (2001). Current trends in whey processing and utilization in Greece. Int. J. Dairy Technol., 54: 14-19. https://doi.org/10.1046/j.14710307.2001.00007.x

-Rathore S, Salmerón I, Pandiella SS (2012). Production of potentially probiotic beverages using single and mixed cereal substrates fermented with lactic acid bacteria cultures. Food Microbiol., 30: 239-244. https://doi.org/10.1016/j. fm.2011.09.001

-Salvatore E, Pes M, Falchi G, Pagnozzi D, Furesi S, Fiori M, Roggio T, Addis MF, Pirisi A (2014). Effect of whey concentration on protein recovery in fresh ovine ricotta cheese.J. Dairy Sci.,97: 4686-4694.https://doi.org/10.3168/ jds.2013-7762

-Sebastian A, Barus T, Mulyono N, Yanti (2018). Effects of fermentation and sterilization on quality of soybean milk. Int. Food Res. J., 25: 2428-2434.

- Sharma A, Noda M, Sugiyama M, Ahmad A, Kaur B (2021). Production of functional buttermilk and soymilk using Pediococcus acidilactici BD16 (alaD+). Molecules, 26: 4671. https://doi.org/10.3390/molecules26154671

-Shiby VK, Radhakrishna K, Bawa AS (2013). Development of whey-fruit-based energy drink mixes using D-optimal mixture design. Int. J. Food Sci. Technol., 48: 742-748. https://doi.org/10.1111/ijfs.12022

- Shukla M, Jha YK, Admassu S (2013). Development of probiotic Beverage from Whey and Pineapple Juice. J. Food Process Technol., 4: 206. https://doi.org/10.4172/21577110.1000206

- Sinha R, Radha C, Prakash J, Kaul P (2007). Whey protein hydrolysate: Functional properties, nutritional quality, and utilization in beverage formulation. Food Chem., 101: 1484- 
1491. https://doi.org/10.1016/j.foodchem.2006.04.021

-Skryplonek K, Jasińska M (2017). Whey-based beverages. Electron J. Polish Agric. Univ., 20(4). https://doi. org/10.30825/5.EJPAU.36.2017.20.4

- Smithers GW (2008). Whey and whey proteins-from "gutter-to-gold. Int. Dairy J., 18(7): 695-704. https://doi. org/10.1016/j.idairyj.2008.03.008

-Tamime AY (2006). Fermented Milk. Blackwell Publishing Company, UK. https://doi.org/10.1002/9780470995501

-Walsh H, Ross J, Hendricks G, Guo M (2010).Physico-chemical properties, probiotic survivability, microstructure, and acceptability of a yogurt-like symbiotic oats-based product using pre-polymerized whey protein as a gelation agent. J. Food Sci., 75: M327-M337. https://doi.org/10.1111/ j.1750-3841.2010.01637.x

-Wesołowska-Trojanowska M, Targoński Z (2014). The whey utilization in biotechnological processes. Nauki Inżynierskie i Technologie, 1(12): 102-119. https://doi.org/10.15611/ nit.2014.1.07

-Wu SC, Su YS, Cheng HY (2011). Antioxidant properties of Lactobacillus-fermented and non-fermented Graptopetalum paraguayense $\mathrm{E}$. Walther at different stages of maturity. Food Chem., 129: 804-809. https://doi. org/10.1016/j.foodchem.2011.05.025 